\title{
Optimal Iron Oxides for Obtaining Hexaferrites
}

\author{
J. Dufour, R. Latorre, C. Negro, F. López-Mateos, E.M. Alcalá* and A. Formoso**
}

Dpto. Ingeniería Química, Facultad de Ciencias Químicas, Universidad Complutense de Madrid, Avda. Complutense s/n, 28040 Madrid, Spain

* Dpto. Fisica de Materiales, Facultad de Ciencias Fisicas, Universidad Complutense de Madrid, Avda. Complutense s/n, 28040 Madrid, Spain

** Dpto. Metalurgia Primaria y Reciclado de Materiales, Centro Nacional de Investigaciones Metalúrgicas, Avda. Gregorio del Amo, $n^{\circ}$ 8, 28040 Madrid, Spain

\begin{abstract}
Presently, the ferrites industry consumes large amounts of iron oxides obtained by spray roasting of steel pickling liquors. The aim of this paper is to propose the synthesis of optimal iron oxides by oxyprecipitation of steel pickling liquors in order to obtain Bahexaferrite with high magnetic properties using the ceramic process. As a raw material. it was used sulphuric liquors with iron concentration of $43 \mathrm{~g} / \mathrm{l}$. The studied variables for the oxyprecipitation step were temperature, $\mathrm{pH}$. stirring speed. flow of oxidizer to obtain goethite and magnetite. The samples were characterized by XRD and SEM. These oxides were wet milled with barium carbonate and the mixture was calcined in order to obtain Ba-hexaferrite. A VSM was used for determine the magnetic properties and the morphology was studied by XRD and SEM. With these results five iron oxides were selected and the conditions of the ceramic process (calcination temperature and time) for obtaining hexaferrite were optimized versus $\mathrm{H}_{\mathrm{c}}$.
\end{abstract}

\section{INTRODUCTION.}

Chemical pickling is an industrial process designed to eliminate the surface layer of iron oxides that it forms in iron industry processes which are exposed to atmospheric oxidation or in the different stages involved in the production of strip iron. With regard to the working of the iron in rolling lines, different types of oxides are produced which make the so-called rust that reduces the resistance of iron structures [l]. Technically, the process involves dissolving the oxide with acid, and then washing with water to get rid of the remaining acid and dissolved iron. The surface oxides enter into the solution in the form of sulphate to make what are known as pickle liquors. The great amount of iron of these liquors makes them appropriated to be used as iron raw material to synthesize Ba-hexaferrite.

\section{EXPERIMENTAL METHOD.}

The iron presented in the liquors is in its ferrous form, so it is necessary to oxidized Fe(II) to Fe(III), totally or partially, to precipitate it. The oxyprecipitation was carried out using a glass made reactor closed with a lid that has five openings for inserting the diffuser, stirrer, thermometer, condenser and the system for adding the basic agent. The reactor also has a side opening for inserting the $\mathrm{pH}$ electrode. The variables and their ranges were: temperature $\left(20-70^{\circ} \mathrm{C}\right), \mathrm{pH}(3.5-6.5)$, stirring speed $\left(250-1000\right.$ rev $\left.\cdot \mathrm{min}^{-1}\right)$ and flow of oxidizer (5-20 l/min) [2]. The liquour w'as provided by ENSIDESA (Aviles) Spain with an iron concentration of $43 \mathrm{~g} / \mathrm{l}$. In these conditions magnetite, goethite and mixtures of them are obtained [3]. To study the optimal conditions for obtaining goethite and magnetite we used X-ray diffraction intensity peak. We used the characteristics XRD intensity peak at $4,18 \AA$ for goethite and $2,53 \AA$ for magnetite. The intensity of diffraction peak give us idea about the cristallinity, grain size and other physic parameters in a quickly way.

\subsection{Synthesis of goethite.}

With the variables studied and the level of these variables we used a $2^{3}$ design (20 experiments) that, by multiple regression corrected for the curvature effects gives the following equation:

$$
I\left(\text { pulses } / \mathrm{cm}^{2}\right) \cdot-2652,76-181,39 p H^{2}+1483,35 p H \cdot 0,105 \mathrm{~N}\left(\text { rev・min }{ }^{-1}\right)
$$


valid for the intervals: Temperature $70^{\circ} \mathrm{C} ; \mathrm{pH}: 3,5-4,5 ; \mathrm{N}$ (stining speed): $500-1000 \mathrm{rev} \cdot \mathrm{mint}^{*} ; \mathrm{Q}_{\mathrm{o}}$ (oxidizer flow): $10-20 \mathrm{l} / \mathrm{min}$. The oxygen flow (oxidizer agent) has no influence, due to the $\mathrm{pH}$ and the stirring speed minimize its effect. The optimal oxyprecipitation conditions for obtaining goethite were: Temperature: $70^{\circ} \mathrm{C}, \mathrm{pH}: 4,0 ; \mathrm{N}=750 \mathrm{rev} \cdot \mathrm{min}^{-1}$ and oxygen flow $6,6 \mathrm{l} / \mathrm{min}$.

\subsection{Synthesis of magnetite}

Using the same mathematical model than for goethite synthesis, for magnetite we obtain the following equation:

$$
\begin{aligned}
I= & -28255,8+9399,5 p H+0,085 N+73,30 Q_{a}-0,13 p H N+ \\
+ & 0,028 N Q_{a}-755,36 p H^{2}+2,68 \cdot 10^{-4} N^{2}-5,44 Q_{a}^{2}
\end{aligned}
$$

where $I$ is XRD intensity peak at $2,53 \AA$ in pulses $\mathrm{cm}^{-2}, \mathrm{~N}$ is the stiming speed in rev $\mathrm{min}^{-1}$ and $\mathrm{Q}_{\mathrm{a}}$ is the air flow (oxidizer) in $\mathrm{Vmin}$. This equation in valid in the following intervals: $\mathrm{pH}: 5,5-6,5 ; \mathrm{N}: 500-1000 \mathrm{rev} \cdot \mathrm{min}^{-1} ; \mathrm{Q}_{\mathrm{n}}: 5-10 \mathrm{l} / \mathrm{min}$. The optimal oxyprecipitation conditions for obtaining magnetite were: Temperature: $70^{\circ} \mathrm{C}, \mathrm{pH}: 6,5: \mathrm{N}=1000 \mathrm{rev} \bullet \mathrm{min}^{-4}$ and air flow $5 \mathrm{l} / \mathrm{min}$.

\section{SYNTHESIS OF BA-HEXAFERRITE.}

The synthesis of Ba-hexafelrite was done by a ceramic method using a stoichometric rate Fe:Ba [4]. The previous oxides were milled, in ethanol, with barium carbonate and the mixture was calcined at $1100 \% \mathrm{C}$ during one hour with a heat ramp of $25^{\circ} \mathrm{C} / \mathrm{min}$. Table I resumes the obtaining conditions of the iron oxide and the magnetic properties of the calcined product deduced from VSM.

Table I. Experimental results for Ba-hexaferrite formation and the oxyprecipitation conditions.

\begin{tabular}{|c|c|c|c|c|c|c|}
\hline Test & $\mathrm{pH}$ & $\mathrm{N}\left(\mathrm{rev} \cdot \mathrm{min}^{-1)}\right.$ & $\mathrm{Q}(\mathrm{l} / \mathrm{min})$ & Raw Material & $\mathrm{H}_{c}(\mathrm{KA} / \mathrm{m})$ & $\mathrm{M}_{q} \mathrm{M}_{s}$ \\
\hline 1 & 4,0 & 750 & 6,6 (oxygen) & Goethite & 493 & 0,62 \\
\hline 2 & 5,5 & 1000 & 10 (air) & Magnetite & 446 & 0,60 \\
\hline 3 & 5,5 & 1000 & 5 (air) & Magnetite & 462 & 0,63 \\
\hline 4 & 6,5 & 1000 & 5 (air) & Magnetite & 446 & 0,62 \\
\hline 5 & 6,0 & 625 & 3,3 (air) & Magnetite & 406 & 0,63 \\
\hline
\end{tabular}

With these products we have calculated the optimal conditions for obtaining barium hexafenite. They were: Calcination temperature $1100^{\circ} \mathrm{C}$, calcination time $180 \mathrm{~min}$ and a heat rate of $25^{\circ} \mathrm{C} / \mathrm{min}$. In these conditions we obtained the results shown in table II, one for goethite (assay 1) and the best for magnetite (assay 4 ).

Table II. Magnetic properties oblained in optimal conditions

\begin{tabular}{|c|c|c|c|c|c|}
\hline Test & $M_{s}\left(\mathrm{emu} / \mathrm{cm}^{3}\right)$ & $B_{\mathrm{r}}(\mathrm{T})$ & $\mathrm{M}_{s} \mathrm{M}_{s}$ & $\mathrm{H}_{s}(\mathrm{KA} / \mathrm{m})$ & $(\mathrm{BH})_{\max }\left(\mathrm{KJ} / \mathrm{m}^{3}\right)$ \\
\hline 1 & 735 & 0,59 & 0,64 & 517 & 116 \\
\hline 4 & 950 & 0,70 & 0,61 & 525 & 116 \\
\hline
\end{tabular}

\section{CONCLUSIONS}

Ba-hexaferrite, obtained by oxyprecipitation of sulphuric pickling liquors, presents magnetic properties higher than those obtained by commercial magnetite and goethite. Our Ba-hexaferrite would be used as pemanent magnets and they can substitute commercial hexaferrite by less amount of magnetic material due to their high magnetic values.

\section{References}

[1] Bhattacharyya S.. Us Enviro. Prot. Agency Res. Dev. (res) EPA (1981).

[2] Chmielewski T. and Charewicz W.A. Hydrometallurgy. 12 (1984) 21-30.

[3] Kiyama M., and Takada, T. Bull. Chem. Soc. Japan 45 (1972) 1923-1924.

[4] Hibst H. Angew. Chem. Int. Ed. Engl. 21 (1982) 270-282. 